Mutia Aprila Erman, Aldri Frinaldi I Dampak Budaya Kerja dalam Meningkatan Kinerja Pegawai di Dinas Pariwisata, Pemuda dan Olahraga Kabupaten Pesisir Selatan

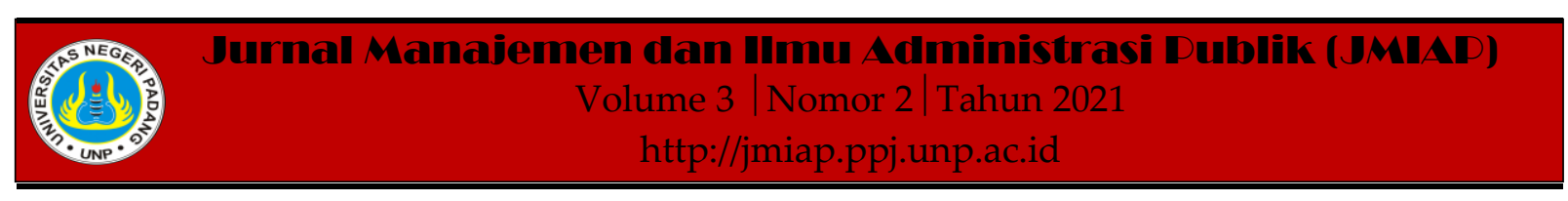

\title{
DAMPAK BUDAYA KERJA DALAM MENINGKATAN KINERJA PEGAWAI DI DINAS PARIWISATA, PEMUDA DAN OLAHRAGA KABUPATEN PESISIR SELATAN
}

\author{
Mutia Aprila Erman ${ }^{1(a)}$, Aldri Frinaldi ${ }^{2(b)}$ \\ ${ }^{1}$ Jurusan Ilmu Administrasi Negara, Universitas Negeri Padang \\ ${ }^{2}$ Jurusan Ilmu Administrasi Negara, Universitas Negeri Padang

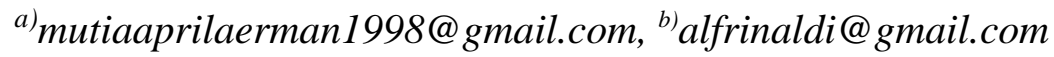

\begin{abstract}
This study is describes the impact of work culture in improving employee performance in DISPARPORA South Coastal Regency. The method used in this research is descriptive qualitative, in the form of written or spoken words from people and observable behavior, it is said that because this method describes or explains the problems that exist by providing answers to the problems presented. Informant selection is done by a purposive sampling method. according to the research that has been done can be said that the impact of work culture improving the performance of employees in DISPARPORA South Coastal District has not had a good impact because there are still some problems that researchers encounter related to work culture, among others: lack of awareness of employees' time to come and go home on time,employees often delay time in completing workers to impact the achievement of unstable performance, communication between employees has not been good so that the lack of cooperation in carrying out duties, and the lack of appreciation and strict sanction given to employees.
\end{abstract}

Keywords : Work Culture, Employee Performance, DISPARPORA Pesisir Selatan Regency

Corresponding author. Email.mutiaaprilaerman1998@gmail.com

How to cite this article. Erman, M. Aprila \& Frinaldi, A. (2021). Dampak Budaya Kerja dalam Meningkatan Kinerja Pegawai di Dinas Pariwisata, Pemuda dan Olahraga Kabupaten Pesisir Selatan. Jurnal Manajemen dan Ilmu Administrasi Publik (JMIAP) Jurusan Ilmu Administrasi Negara Fakultas Ilmu Sosial Universitas Negeri Padang, Volume 3 (2), Hal. 91-99.

http://jmiap.ppj.unp.ac.id

Copyright $\odot 2021$. Published by Labor Jurusan Ilmu Administrasi Negara FIS UNP, Padang 


\section{PENDAHULUAN}

Sumber daya manusia (SDM) ialah faktor yang sangat berpengaruh dalam suatu organisasi, karna tanpa SDM tujuan dan sasaran suatu organisasi tidak tercapai dengan efektif dan efisien. Pentingnya peran SDM bagi organisasi diharapkan bisa meningkatkan kinerja bagi setiap pegawai, untuk itu SDM harus memiliki kemampuan yang baik dalam melaksanakan semua pekerjaan, karna dengan kemampuan yang baik maka secara langsung kinerja pegawai akan meningkat.

Dalam suatu instansi pemerintah, faktor yang sangat berpengaruh kepada kinerja pegawai ialah budaya kerja, karena dengan kebiasaan yang baik dan didukung dengan kerja sama yang baik akan tercapai hasil kerja yang optimal sehingga kinerja pegawai dapat meningkat. Dapat dilihat dalam PERMENPAN dan Reformasi Birokrasi Republik Indonesia Nomor 39 Tahun 2012 Tentang Pedoman Pengembangan Budaya Kerja, budaya kerja ialah sebagai sifat dan ciri khas seseorang dan kelompok orang yang berdasarkan pada nilai yang dipercayai kebenaraannya dan sudah menjadi sifat dan kebiasaan dalam menjalankan tugas dalam kesehariannya.

Kabupaten Pesisir Selatan adalah salah satu daerah yang mengutamakan bidang wisata sebagai penyumbang Pendapatan Asli Daerah. Dalam mendukung hal itu, pemda Kabupaten Pesisir Selatan membentuk Satuan Kerja Perangkat Daerah (SKPD) yang secara khusus menangani bidang kepariwisataan yaitu Dinas Pariwisata, Pemuda dan Olahraga (DISPARPORA) Kabupaten Pesisir Selatan. Dalam pelaksanaannya, sesuai dengan Perda Kabupaten Pesisir Selatan No.4 Tahun 2014, tentang Susunan Organisasi dan Tata Kerja Dinas Daerah pada Bab VII pasal 24 ayat (2). DISPARPORA Kabupaten Pesisir Selatan memiliki 5 fungsi : (1) Perumusan kebijakan teknis di bidang pariwisata dan ekonomi kreatif, pemuda dan olahraga, (2) Penyelenggaraan urusan pemerintah dan pelayanan umum di bidang pariwisata dan ekonomi kreatif, pemuda dan olahraga, (3) Pembinaan dan pelaksanaan tugas di bidang pariwisata dan ekonomi kreatif, pemuda dan olahraga, (4) Pembinaan unit pelaksanaan teknis dinas, (5) Pelaksanaan tugas lainnya yang diberikan oleh pimpinan. Sehubungan dengan fungsi DISPARPORA Kabupaten Pesisir Selatan, sangat menentukan sukses atau tidaknya program pariwisata.

Bidang pariwisata merupakan salah satu faktor andalan di Kabupaten Pesisir Selatan memiliki banyak tempat wisata yang menarik sehingga dijuluki dengan Negeri Sejuta Pesona. Untuk itu perlu budaya kerja pegawai yang positif di DISPARPORA Kabupaten Pesisir Selatan sehingga dapat meningkatkan kinerja pegawai yang optimal dalam melaksanakan pekerjaan dan dapat memajukan objek wisata di Kabupaten Pesisir Selatan dan demi suksesnya program parwisata. DISPARPORA Kabupaten Peisisir Selatan, bukan hanya mengharapkan pegawai yang cakap, dan terampil tetapi yang terpenting mau bekerja dengan rajin dan berkeinginan mencapai hasil kerja yang maksimal.

DISPARPORA Kabupaten Pesisir Selatan memiliki struktur organisasi yang sudah dibentuk dengan baik dan jelas sesuai dengan tugasnya masing-masing. Berikut data pegawai DISPARPORA Kabupaten Pesisir Selatan berdasarkan struktur organisasi yang ada: 


\section{Tabel 1. Jumlah Pegawai DISPARPORA Kabupaten Pesisir Selatan}

\begin{tabular}{clccc}
\hline & \multicolumn{1}{c}{ Jenis } \\
No. & \multicolumn{1}{c}{ Bidang } & \multicolumn{2}{c}{ Kelamin } \\
L & P & Jumlah \\
\hline 1. & $\begin{array}{l}\text { Kepala Dinas } \\
\text { Bidang }\end{array}$ & 1 & - & 1 \\
2. & $\begin{array}{l}\text { Sekretariat } \\
\text { Bidang }\end{array}$ & 3 & 3 & 6 \\
3. & $\begin{array}{l}\text { Pariwisata } \\
\text { Bidang }\end{array}$ & 2 & 5 & 7 \\
4. & $\begin{array}{l}\text { Pemuda dan } \\
\text { Olahraga } \\
\text { Bidang }\end{array}$ & 6 & 1 & 7 \\
5. & $\begin{array}{l}\text { Ekonomi } \\
\text { Kreatif }\end{array}$ & 3 & 4 & 7 \\
6. & $\begin{array}{l}\text { Pegawai } \\
\text { Honorer }\end{array}$ & 18 & 3 & 21 \\
\hline \multicolumn{1}{c}{ Total } \\
\hline
\end{tabular}

(Sumber: Dokumen Absen DISPARPORA Kabupaten Pesisir Selatan, 2020)

Berdasarkan dari tabel di atas dapat dilihat jumlah pegawai di DISPARPORA Kabupaten Pesisir Selatan berjumlah 49 orang yaitu terdiri dari 1 orang Kepala Dinas, 6 orang Bidang Sekretariat, 7 orang Bidang Pariwisata, 7 orang Bidang Pemuda dan Olahraga, 7 orang Bidang Ekonomi Kreatif, dan 21 orang pegawai honorer. Semua bidang yang ada tersebut diharapkan bisa bekerja sama dengan baik sehingga dapat melaksanakan tugasnya masingmasing yang sesuai dengan bidang nya, dan terwujudnya visi dan misi dari DISPARPORA Kabupaten Pesisir Selatan.

Berdasarkan hasil dari wawancara dan observasi yang peneliti lakukan, ada beberapa masalah yang sering terjadi di DISPARPORA Kabupaten Pesisir Selatan yaitu masih adanya pegawai yang kurang akan kesadaran waktu seperti datang terlambat dan tidak mengikuti apel pagi. Dan masih adanya pegawai yang pulang sebelum waktu yang telah diterapkan yaitu pukul 16.00 WIB. Adanya pegawai yang memperpanjang jam istirahat sehingga jam kerja tersita. Namun, sanksi yang tegas tidak ada diberikan kepada pegawai yang sering datang terlambat dan tidak adanya penghargaan kepada pegawai yang selalu datang tepat waktu.

Masalah selanjutnya yaitu pegawai sering keluar ruangan pada saat jam kerja. Adanya pegawai yang menggunakan jam kerja bukan untuk menyelesaikan tugasnya dengan cepat tapi malah bersantai-santai seperti bermain handphone. Sehingga akan berdampak kepada pencapaian kinerja pegawai di DISPARPORA Kabupaten Pesisir Selatan yang tidak stabil.

Masalah selanjutnya yaitu komunikasi. Kurangnya interaksi sesama pegawai. Hubungan kurang baik antar pegawai tidak saling bertegur sapa, dalam bekerja komunikasi yang terjalin di DISPAPORA Kabupaten Pesisir Selatan tidak lancar sehingga akan mengganggu kerja sama antara sesama rekan kerjanya dan pegawai tidak menyelesaikan tugas yang di berikan dengan efektif dan efisien.

Budaya kerja pegawai di DISPARPORA Kabupaten Pesisir Selatan dalam melaksanakan tugasnya belum sesuai dengan yang di harapkan. Masih ada beberapa hal terkait budaya kerja pegawai yang harus ditingkatkan dan diperbaiki lagi. Salah satu cara dalam meningkatkan pencapaian kinerja pegawai adalah dengan menerapkan budaya kerja positif dalam organisasi. Karena jika budaya kerja pegawai sudah baik, otomatis kinerja pegawai akan maksilmal dan sebaliknya juga begitu.

Dari uraian yang peneliti jelaskan di atas, maka peneliti mempunyai ketertarikan meneliti dengan topik "Dampak Budaya Kerja dalam Meningkatan Kinerja Pegawai di DISPARPORA Kabupaten Pesisir Selatan".

Tujuan dari penelitian ini ialah nuntuk mengetahui Bagaimanakah Dampak Budaya Kerja Dalam Meningkatkan Kinerja Pegawai di DISPARPORA Kabupaten Pesisir Selatan?. 


\section{TINJAUAN PUSTAKA}

\section{Konsep Dampak}

Dalam Kamus Besar Bahasa Indonesia, dampak adalah pukulan, akibatnya ada akibat positif dan negatif. Pengaruh adalah suatu kondisi dimana terdapat interaksi antara dan lainnya atau sebab akibat antara apa yang mempengaruhi dan apa yang terpengaruh (Suharno \& Retnoningsih, 1997).

Dampak terbagi atas dua pengertian:

1. Dampak Positif

Dampak adalah keinginan untuk meyakinkan, membujuk, mempengaruhi atau mengesankan orang lain untuk mengikuti atau mendukung keinginannya. Positif adalah keadaan mental seseorang yang didukung oleh upaya sadar ketika sesuatu terjadi pada dirinya, agar tidak mengganggu fokus mental pada hal negatif. Orang yang berpikir positif, tahu bahwa mereka berpikir buruk, akan segera pulih.

Dampak positif adalah keinginan untuk meyakinkan, membujuk, mempengaruhi atau mengesankan orang lain dengan tujuan mengikuti atau mendukung keinginan baik mereka.

2. Dampak Negatif

Menurut Kamus Besar Bahasa Indonesia, pengaruh negatif merupakan pengaruh kuat yang membawa akibat negatif. Dampak adalah keinginan untuk meyakinkan, membujuk, mempengaruhi seseorang untuk mengikuti atau mendukung keinginannya. (Suharno \& Retnoningsih, 1997).

Dampak negatif adalah keinginan untuk meyakinkan, membujuk, mempengaruhi atau mengesankan seseorang untuk mengikuti atau mendukung keinginan buruknya dan memiliki akibat tertentu.

\section{Konsep Budaya Kerja}

Triguno (1995) dikatakan bahwa budaya kerja adalah filosofi yang didasarkan pada pandangan hidup sebagai nilai-nilai karakteristik, kebiasaan dan kekuatan pendorong yang tertanam dalam kehidupan kelompok masyarakat dan organisasi yang terlihat dalam sikap, keyakinan, keinginan, pendapat dan tindakan yang terwujud dalam "bekerja". Atau "bekerja". Moeheriono, (2014) bahwa budaya kerja adalah sudut pandang orangorang yang sejalan dengan kondisi hati yang dilandasi oleh keyakinan yang diyakini berkaitan dengan pekerjaan.

Menurut Frinaldi, (2017) budaya kerja adalah sebagai landasan yang dapat dilihat atau tidak terlihat pada diri individu, dilihat pada segi nilai dan keyakinan, pemahaman tentang bagaimana cara kerja, norma, cara berpikir dan perilaku individu atau kelompok yang bisa membantu tercapainya tujuan organisasi dengan kepemimpinan yang baik, komunikasi yang sehat, pemahaman tentang waktu, penghargaan dan hukuman yang adil.

Menurut Frinaldi et al., (2020) bahwa budaya kerja erat kaitannya dengan pemberdayaan pegawai dalam suatu organisasi. Budaya kerja dapat membantu kinerja pegawai karena budaya kerja menciptakan motivasi tinggi bagi pegawai untuk memanfaatkan peluang yang diberikan organisasi dengan sebaikbaiknya. nilai persatuaan memungkinkan pegawai merasa nyasa dalam bekerja, menunjukkan komitmern dan loyalitas, serta mempertahankan keunggulan kompetitif. Semakin kuat budaya kerja, semakin banyak insentif yang dimiliki pegawai untuk bergerak bersama organisasi.

Menurut Kasandra et al., (2018) Budaya kerja pada suatu organisasi yang didasarkan dengan pedoman pada kualitas hidup sebagai nilai ke dalam prilaku ataupun sifat yang menjadi pendorong bagi segelintir masyarakat maupun pada suatu organisasi.

Menurut Frinaldi, (2014) Jika instansi memiliki budaya kerja positif yang kuat di tempat kerja, ada sinergi antara karyawan tetap dan manajernya, pimpinan jangan buang waktu. Pemikiran dan energi dimaksudkan hanya untuk menyelesaikan konflik di antara mereka karena perbedaan nilai budaya yang dianut dalam pekerjaan untuk menentukan tingkat keberhasilan kerja karyawan secara keseluruhan atau 
untuk periode tertentu dalam pelaksanaan tugas atau tujuan, kriteria yang dimaksud adalah ditentukan sebelumnya dan disepakati.

Menurut Frinaldi, (2017) ada enam unsur yang dapat melihat dan mengukur budaya kerja dalam organisasi dan institusi, yaitu (1)Kepemimpinan, (2)Penampilan, (3)Kesadaran akan Waktu, (4)Komunikasi, (5)Penghargaan dan Pengakuan , (6) Nilai dan Kepercayaan.

\section{Konsep Kinerja Pegawai}

Kata Kinerja berasal dari bahasa Inggris yaitu Job performance atau actual performance atau level of performance yaitu tingkat keberhasilan seorang pegawai dalam melakukan dan menyelesaikan tugasnya. Kinerja bukan merupakan ciri seseorang, seperti bakat dan kemampuan, tetapi ialah wujud dari bakat dan kemampuan itu sendiri dalam bentuk nyata, sehingga dapat diartikan bahwa kinerja adalah hasil dari pekerjaan yang dilakukan oleh pegawai dalam menjalankan tugas dan pekerjaan yang bersumber dari organisasi. (Sumardjo, 2018).

Menurut Bernardin dan Russel (Keban, 2008) Kinerja adalah hasil dari melakukan fungsi pekerjaan tertentu atau bertindak dalam posisi tertentu untuk jangka waktu yang telah ditentukan sebelumnya. Hasil kerja yang dimaksud adalah hasil dari kemampuan, pengalaman dan keinginan yang dicapai.

Mathias dan Jackson (Tisnawati, 2018) mengatakan bahwa kinerja pegawai pada dasarnya adalah apa yang dia lakukan atau tidak lakukan saat melakukan pekerjaannya. Rivai dan Sagala (Tisnawati, 2018) dikatakan bahwa kinerja pegawai merupakan hubungan yang nyata yang masing-masing mewujudkan dirinya sebagai produktivitas yang dihasilkan pegawai sesuai dengan perannya dalam organisasi. Milkovich dan Boudreau (Tisnawati, 2018) menyatakan bahwa kinerja pegawai adalah kinerja pegawai dalam kondisi yang telah ditentukan sebelumnya.
Sumardjo, (2018) mengatakan bahwa terdapat enam indikator untuk melihat kinerja pegawai, yaitu:

a. Kuantitas Pekerjaan (Quantity Work), mengacu pada jumlah pekerjaan yang dapat diselesaikan dengan tepat waktu.

b. Kualitas Kerja (Quality of Work), berkaitan dengan ketepatan, ketepatan dan kelengkapan dalam pelaksanaan tugas dalam organisasi.

c. Kemandirian (Dependability), mengacu pada kemampuan seorang pegawai untuk bekerja secara mandiri atau dengan kesadaran atau keyakinan akan kehadiran.

d. Inisiatif (Initiative), terkait dengan fleksibilitas berpikir dan kemauan untuk bertanggung jawab.

e. Adaptabilitas (Adaptability), berkaitan dengan kemampuan beradaptasi dengan lingkungan.

f. Kolaborasi (Cooperation), terkait dengan kemampuan bekerja secara tulus dengan pimpinan, atasan dan lain-lain.

Menurut Mathis dan Jackson dalam (Damayanti et al., 2018) terdapat lima elemen kinerja pegawai antara lain:

a. Jumlah hasil, diukur dengan persepsi pegawai tentang jumlah tindakan yang ditugaskan dan hasilnya.

b. Kualitas hasil, dilihat dari sudut pandang karyawan untuk kualitas pekerjaan yang dilakukan dan kesempurnaan tugas yang ditetapkan dalam kaitannya dengan keterampilan dan kemampuan pegawai.

c. Ketepatan waktu hasil, dilihat dari persepsi pegawai terhadap kegiatan yang dilakukan dari waktu mulai hingga keluar. Anda dapat menyelesaikannya pada waktu yang dijadwalkan dan memaksimalkan waktu yang tersedia.

d. Absensi, tingkat absensi karyawan di perusahaan dapat menentukan produktivitas karyawan. 
e. Kemampuan bekerja sama, dilihat dari kemampuan pegawai untuk bekerja bersama dengan rekan kerja dan lingkungannya.

Indikator kinerja pegawai juga dikemukakan oleh Sastrohadiwiryo, (2002) yaitu:

a. Kesetiaan, artinya tekad dan kemampuan untuk patuh, untuk menyadari dan mempraktekkan apa yang dipatuhi dengan kesabaran dan tanggung jawab yang besar.

b. Efisiensi kerja ialah hasil kerja yang dilakukan oleh pegawai saat melaksanakan pekerjaan yang diberikan kepadanya.

c. Tanggung jawab adalah kemampuan pegawai untuk melakukan tugas yang ditugaskan kepadanya dengan baik.

d. Kepatuhan adalah kemampuan pegawai untuk mematuhi semua hukum dan peraturan yang berlaku.

e. Kejujuran adalah ketulusan pegawai dalam bertindak untuk tidak menyalahgunakan kekuasaannya.

f. Kolaborasi adalah kemampuan pegawai untuk bekerja sama dengan orang lain dalam melaksanakan tugas dan pekerjaannya.

g. Inisiatif adalah kemampuan seorang pegawai dalam pengambilan keputusan baik secara bertahap maupun melakukan semua tindakan yang diperlukan saat menjalankan tugas-tugas dasar, tanpa menunggu atasan.

h. Kepemimpinan adalah kemampuan untuk mempengaruhi seseorang sedemikian rupa sehingga bisa dimaksimalkan pada saat menyelesaikan tugas.

\section{METODE PENELITIAN}

Metode yang digunakan dalam penelitian ini yaitu metode kualitatif deskriptif. Untuk lokasi nya di DISPARPORA Kabupaten Pesisir Selatan. Data yang digunakan yaitu data primer dan data sekunder. Data dikumpulkan menggunakan teknik observasi, wawancara, dan dokumentasi. Teknik triangulasi yaitu digunakan untuk menguji keabsahan data dengan menggunakan pihak luar sebagai perbandingan sehingga bisa ditarik suatu kesimpulan. Untuk teknik analisis data yang digunakan yaitu: pengumpulan data, reduksi data, penyajian data dan penarikan kesimpulan. Pemilihan informan dilakukan dengan metode purposive sampling.

\section{HASIL DAN PEMBAHASAN}

Untuk melihat bagaimana dampak budaya kerja dalam peningkatkan kinerja oleh pegawai di DISPARPORA Kabupaten Pesisir Selatan maka dilihat dengan menggunakan teori budaya kerja. Menurut Aldri Frinaldi (2017) ada beberapa unsur yang harus terpenuhi dalam budaya kerja diantaranya sebagai berikut:

\section{Kepemimpinan}

Berdasarkan temuan peneliti, kepemimpinan dalam peningkatan kinerja pegawai di DISPARPORA Kabupaten Pesisir Selatan sudah berdampak baik, karena dengan pengalaman dan kemampuan yang dimiliki pimpinan sangat cukup untuk menggerakan pegawai DISPARPORA Kabupaten Pesisir Selatan dalam bekerja. Pemimpin membagi tugas pegawai seusai dengan tupoksi yang telah dikeluarkan oleh kepala daerah. Pimpinan juga melakukan pertemuan untuk memberikan pembekalan berupa pelatihan dan sosialisasi kepada pegawai yang akan menjalankan tugas, selain itu pimpinan juga memberi kesempatan yang sama kepada pegawai dalam pengambilan keputusan.

Kepemimpinan sangat penting dan berpengaruh pada kinerja pegawai dalam suatu organisasi karena jika pemimpinnya bagus dan tegas maka pegawainya juga terarah dengan baik, dimana setiap pekerjaan harus diarahkan secara baik oleh pemimpin. Jika tidak maka bawahannya juga ikut tidak terarah dan tidak disiplin. Pegawai juga membutuhkan sosok 
pemimpin yang bisa menjadi pedoman bagi mereka dalam bekerja.

\section{Penampilan}

Berdasarkan temuan yang peneliti dapatkan bahwa pegawai dalam bekerja telah berpenampilan rapi dan lengkap dengan tanda pengenalnya. Hal ini sudah berdampak baik karena telahsesuai dengan aturan yang di terapkan di DISPARPORA Kabupaten Pesisir Selatan.

Penampilan merupakan salah satu faktor penting yang dimiliki pegawai dalam pekerja karena penampilan bentuk dari kedisiplinan. Penampilan yang rapi dan sopan akan membuat suasana dalam bekerja menjadi nyaman dan rekan kerja juga merasa senang melihatnya. Penampilan yang rapi dan sopan merupakan aturan yang harus di ikuti oleh setiap pegawai di DISPARPORA Kabupaten Pesisir Selatan. Jika penampilan pegawai telah sesuai dengan aturan maka kinerja nya akan dinilai baik.

\section{Kesadaran Akan Waktu}

Berdasarkan temuan yang peneliti dapatkan di lapangan, dengan kurangnya kesadaran akan waktu oleh pegawai seperti keterlambatan pegawai datang kekantor dan pulang sebelum waktunya, serta masih adanya pegawai yang menuda-nunda dalam melaksanakan tugasnya sehingga target pekerjaannya tidak sampai dan selesai lebih dari waktu yang telah ditentukan dan akan menghambat tujuan organisasi. Hal ini tentu belum berdampak baik kepada pencapaian kinerja pegawai karena berdasarkan data yang didapatkan pencapian kinerja pegawai di DISPARPORA Kabupaten Pesisir Selatan tidak stabil.

Kesadaran akan waktu merupakan aspek yang harus di penuhi oleh pegawai dalam bekerja, seperti datang tepat pada waktunya dan pulang sesuai aturan waktu yang diterapkan, karena pegawai yang sadar akan waktu dalam bekerja tentu pekerjaan akan berjalan dengan efektif dan kinerja nya akan meningkat. Jika sebaliknya pegawai tidak hadir tepat waktu, pulang sebelum waktunya dan sering menunda-nunda dalam menyelesaikan pekerjaan maka itu akan menjadi kelemahan tersendiri bagi DISPARPORA Kabupaten Pesisir Selatan karena memiliki pegawai yang tidak disiplin dalam menggunakan waktu kerja dan mengakibatkan pekerjaan terhambat tidak selesai tepat pada waktunya. Hal inilah yang terjadi di DISPARPORA Kabupaten Pesisir Selatan dan tidak berdampak baik terhadap kinerja pegawai.

\section{Komunikasi}

Berdasarkan temuan yang peneliti dapatkan di lapangan, komunikasi yang terjalin antar pegawai dan pimpinan di DISPARPORA Kabupaten Pesisir Selatan sudah baik, hal ini dapat dilihat ketika rapat pimpinan memberikan informasi dengan jelas dan dapat di mengerti langsung oleh pegawai. Selain itu pimpinan juga memberikan kesempatan yang sama kepada pegawai dalam pengambilan keputusan.

Komunikasi yang terjalin antar sesama pegawai masih kurang baik, karena masih ada yang tidak saling bertegur sapa. Adanya pegawai yang tidak mau bekerjasama jika rekan kerjanya mengalami kesulitan dalam melaksanakan tugas. Hal ini belum berdampak baik terhadap peningkatan kinerja pegawai karena dalam melaksanakan tugas tentu perlu komunikasi yang baik dengan sesama pegawai sehingga terciptanya hasil kerja yang optimal. Jika komunikasi yang terjalin tidak baik tentu akan berdampak dalam penyelesaikan tugas tidak efesien dan efektif.

\section{Penghargaan dan Pengakuan}

Berdasarkan temuan peneliti di lapangan, tidak adanya penghargaan yang diberikan kepada pegawai yang telah bekekerja dengan baik, jika adanya penghargaan pegawai akan termotivasi dalam bekerja untuk lebih baik lagi karena mereka merasa hasil kerjanya dihargai dan diakui. Sedangkan bagi pegawai yang melanggar aturan dan tidak bekerja dengan baik tidak ada diberi sanksi yang tegas bagi pemimpin. Harusnya jika ada pegawai yang 
tidak taat aturan di berikan sanksi yang tegas agar bisa jadi bentuk pembelajaran dan bentuk penegak kedisiplinan bagi pegawai di DISPARPORA Kabupaten Pesisir Selatan. Hal ini belum berdampak baik terhadap pencapaian kinerja pegawai, karena belum adanya sanksi dan penghargaan yang diberikan kepada pegawai sehingga pegawai sering lalai dalam bekerja.

\section{Nilai dan Kepercayaan}

Berdasarkan temuan yang peneliti dapatkan di lapangan, nilai-nilai dan kepercayaan yang diterapkan di DISPARPORA Kabupaten Pesisir Selatan berlandaskan pada tupoksi yang dikeluarkan oleh Kepada Daerah tertuang dalam Perda Kabupaten Pesisir Selatan No.4 Tahun 2014 tentang Susunan Organisasi da Tata Kerja Dinas Daerah. Hal ini sudah berdampak baik karena pegawai bekerja sudah sesuai dengan nilai dan kepercayaan yang ada.

\section{PENUTUP}

Peneliti dapat menyimpulkan bahwa Dampak Budaya Kerja Dalam Meningkatkan Kinerja Pegawai di DISPARPORA Kabupaten Pesisir Selatan belum berdampak baik terhadap peningkatan kinerja pegawai karena masih ada beberapa masalah terkait budaya kerja yaitu:

a) Kurangnya kesadaran akan waktu oleh pegawai seperti keterlambatan pegawai datang kekantor dan pulang sebelum waktunya, serta masih adanya pegawai yang menuda-nunda dalam melaksanakan tugasnya sehingga tidak selesai dengan cepat.

b) Kurang baiknya komunikasi yang terjalin antar sesama pegawai dan kurangnya kerjasama jika rekan kerjanya mengalami kesulitan dalam melaksanakan tugas.

c) Tidak adanya penghargaan yang diberikan kepada pegawai terkait kinerja pegawai dan kurangnya sanksi tegas yang diberikan kepada yang melanggar aturan sehingga pegawai kurang sadar akan kesalahannya dan kurang termotivasi dalam bekerja. Hal tersebut tentu belum berdampak baik terhadap peningkatan kinerja pegawai DISPARPORA Kabupaten Pesisir Selatan.

Melihat masalah yang terjadi dilapangan dengan masih adanya terdapat beberapa masalah pada budaya kerja pegawai di DISPARPORA Kabupaten Pesisir Selatan maka peneliti menyarankan

a) Diharapkan kepada pegawai di DISPARPORA Kabupaten Pesisir Selatan untuk tidak datang terlambat ke kantor dan pulang tepat pada waktu yang telah ditentukan.

b) Diharapkan untuk memberikan penghargaan kepada pegawai yang telah bekerja dengan baik agar mereka termotivasi dalam bekerja. Serta diharapkan memberikan sanksi yang tegas kepada pegawai yang telah melanggar aturan.

c) Diharapkan kepada semua pegawai untuk saling berkomunikasi dengan sehat antara sesama rekan kerja sehingga terjalin kerja sama yang baik dalam bekerja dan pekerjaan dapat diselesaikan tepat pada waktunya.

\section{DAFTAR KEPUSTAKAAN}

Damayanti, R., Hanafi, A., \& Cahyadi, A. (2018). Pengaruh Kepuasan Kerja Terhadap Kinerja Karyawan (Studi Kasus Karyawan Non Medis Rs Islam Siti Khadijah Palembang). Jembatan, 15(2), 75-86. https://doi.org/10.29259/jmbt.v15i2.66 55

Frinaldi, A. (2014). Pengaruh Budaya Kerja Pegawai Negeri Sipil Terhadap Pelayanan Publik Di Dinas Catatan Sipil Dan Kependudukan Kota Payakumbuh. Humanus, 13(2), 180. https://doi.org/10.24036/jh.v13i2.4727 
Frinaldi, A. (2017). Mengelola Budaya Organisasi dan Budaya Kerja. UNP PRESS.

Frinaldi, A., Putri, N. E., \& Jumiati. (2020). The Influence of Work Culture and Work Quality on Service Quality in 50 Kota Regency, West Sumatra. 1, 1-11. https://doi.org/10.2991/assehr.k.20121 9.055

Kasandra, D., Frinaldri, A., \& Lanin, D. (2018). Pengaruh Budaya Kerja Pengemudi Angkutan Umum Kota Terhadap Kepuasan Penumpang di Kota Padang. Spirit Publik, 13(1), 3849.

Keban, Y. T. (2008). Enam Dimensi Strategis Administrasi Publik "Konsep Teori, dan Isu". Gaya Media.

Moeheriono. (2014). Pengukuran Kinerja Berbasis Kompetensi Edisi Revisi. Rajawali Pers.

Sastrohadiwiryo, S. (2002). Manajemen Tenaga Kerja Indonesia: Pendekatan Administrasi dan Operasional. PT. Bumi Aksara.

Sumardjo, M. (2018). Manajemen Pengembangan Sumber Daya Manusia. Alfabeta.

Tisnawati, E. (2018). Kepemimpinan dan Perilaku Organisasi "Membangun Organisasi Unggul di Era Perubahan.” PT. Refika Aditama.

Triguno. (1995). Budaya Kerja: Menciptakan Lingkungan yang Kondusive untuk Meningkatkan Produktivitas Kerja. Golden Terayon. 